\title{
Antifeedant activity and growth inhibition effects of some plant extracts against larvae of Colorado potato beetle [Leptinotarsa decemlineata Say (Col: Chyrsomelidae)] under laboratory conditions ${ }^{1}$
}

\begin{abstract}
Bazı bitki ekstraktlarının laboratuvar koşullarında Patates böceği [Leptinotarsa decemlineata Say (Col: Chyrsomelidae)] larvaları üzerine beslenme engelleyici ve larval gelişmeyi engelleyici etkileri

\author{
Mustafa ALKAN ${ }^{*}$
}

\author{
Kenan KARA ${ }^{4}$
}

Summary

Antifeedant activity and growth inhibition effects of Achillea millefolium L. (Asteraceae), Heracleum platytaenium Boiss (Apiaceae), and Humulus lupulus L. (Cannabaceae) extracts were tested on the third instar larvae of Colorado potato beetle (Leptinotarsa decemlineata Say, Col: Chyrsomelidae) under laboratory conditions. Plant extracts were obtained treating "cones" of $H$. lupulus, leaves and stems of $H$. platytaenium and leaves, stems and flowers of $A$. millefolium with methanol using maceration technique. The plant extracts $(50 \mathrm{~g} / \mathrm{L})$ were applied to potato leaflets and consumption area for individual insect was measure with a planimeter after 24,48 and $72 \mathrm{~h}$. The single dose screening bioassay revealed that all tested plant extracts possessed antifeedant activity against the beetle larvae at $50 \mathrm{~g} / \mathrm{L}$ concentration and average consumed leaf area were $0.04 \mathrm{~cm}^{2}, 0.05 \mathrm{~cm}^{2}$ and $0.30 \mathrm{~cm}^{2}$ for $H$. lupulus, $H$. platytaenium and A. millefolium respectively. In dose response bioassay, it was revealed that there was a negative correlation between the averages consumed leaflet area and the plant extract dose. The greatest antifeedant activity was seen in $H$. lupulus extract treated leaflets at $10 \mathrm{~g} / \mathrm{L}$ concentration and the average consumed leaflet area was $0.68 \mathrm{~cm}^{2}$ after $72 \mathrm{~h}$. The $H$. platytaenium and $H$. lupulus extracts had similar effects on the larval growth indices. Both plants extracts had 1.2 growth index values at $30 \mathrm{~g} / \mathrm{L}$ concentration. These results indicate that the $H$. platytaenium and $H$. lupulus extracts could have significant potential as antifeedant and larval growth inhibition agent in the control of larvae of Colorado potato beetle.
\end{abstract}

Keywords: Antifeedant effect, Colorado potato beetle, Heracleum platytaenium, Humulus lupulus, plant extract

\section{Özet}

Bu çalışmada Achillea millefolium L. (Asteraceae), Heracleum platytaenium Boiss (Apiaceae), Humulus lupulus L. (Cannabaceae) ekstraktının Patates böceği (Leptinotarsa decemlineata Say, Col: Chyrsomelidae) üzerindeki beslenmeyi engelleyici ve larval gelişmeyi engelleyici etkileri laboratuvar şartlarında test edilmiştir. Bitki ekstraktlarını eldesinde $H$. lupulus'un kozalakları, $H$. platytaenium'un gövde ve yaprakları, $A$. millefolium'un ise çiçekleri kullanılmış ve maserasyon tekniği kullanılarak metanol ekstraktları elde edilmiştir. Bitki ekstraları $(50 \mathrm{~g} / \mathrm{L})$ patates yapraklarına uygulanmış ve her bir böceğin tükettiği yaprak alanı 24,48 ve 72 saat sonra planimetre ile ölçülmüşsür. Tek doz tarama testlerinde tüm bitki ekstraktları $50 \mathrm{~g} / \mathrm{L}$ konsantrasyonda beslenme engelleyici etkiye sahip olmuş ve ortalama yaprak tüketim alanı $H$. lupulus, H. platytaenium, A. millefolium için sırasıyla $0.04 \mathrm{~cm}^{2}, 0.05 \mathrm{~cm}^{2}$ ve $0.30 \mathrm{~cm}^{2}$ olarak hesaplanmışıtı. Doz-etki denemelerin de ortalama yaprak tüketim alanı ile doz arasında negatif bir ilişki saptanmışır. En yüksek beslenmeyi engelleyici etki $10 \mathrm{~g} / \mathrm{L}$ konsantrasyonda $H$. lupulus ekstraktında 72 . saat sonunda $0.68 \mathrm{~cm}^{2}$ yaprak tüketim alanı ile görülmüştür. $H$. lupulus ve $H$. platytaenium ekstraktları larval gelişme indeksi üzerine benzer etkilere sahip olmuşlardır. Her iki bitki ekstraktı $30 \mathrm{~g} / \mathrm{L}$ konsantrasyonda 1.2 gelişme indeks değerine sahip olmuştur. Bu sonuçlar $H$. lupulus ve $H$. platytaenium ekstraktlarının patates böceğine karşı beslenme engelleyici ve larval gelişmeyi engelleyici etkilerinin olduğunu ortaya koymaktadır.

Anahtar sözcükler: Beslenmeyi engelleyici etki, patates böceği, Heracleum platytaenium, Humulus lupulus, bitki ekstraktı

\footnotetext{
${ }^{1}$ This article has been drawn up from a certain part of the doctoral project of Mustafa Alkan which is promoted within the scope of the Project no. TAGEM-BS-12 / 04-04 / 01- 04 and this study was presented as a poster presentation at the International Conference on Biopesticide 7. 19-25 October 2014

${ }^{2}$ Plant Protection Central Research Institute, Ankara, Turkey

${ }_{4}^{3}$ Department of Plant Production and Technologies, Faculty of Agricultural Sciences and Technologies, Nigde University, Niğde, Turkey

${ }^{4}$ Department of Plant Protection, Faculty of Agriculture, Gaziosmanpasa University, Tokat, Turkey

* Sorumlu yazar (Corresponding author) e-mail: mustafa_alkan@ziraimucadele.gov.tr

Alınış (Received): 01.06.2015 Kabul ediliş (Accepted): 23.11.2015 Çevrimiçi Yayın Tarihi (Published Online): 04.12.2015
} 


\section{Introduction}

The potato (Solanum tuberosum (L.) (Solanaceae) crop is attacked by many pests in the fields and stores, which may lead to significant qualitative and quantitative losses. One of the most important potato pests is Colorado potato beetle (CPB) (Leptinotarsa decemlineata Say, Coleoptera: Chyrsomelidae). The beetle feeds on all vegetative part of potato and sometimes causes 100 percent loss, unless insect control. The beetle is also vector of bacterial potato ring rot disease (Christie et al., 1991). Application of conventional insecticides is the effective control method against $L$. decemlineata but they have some limitations as well. The incremental and uncheck application of insecticides may cause phyto-toxicity and lead towards insecticide resistance development (Stewart et al., 1997; Mota-Sanchez et al., 2000; Whalon et al., 2011; Afzal et al., 2014).

Colorado potato beetle rapidly develops resistance to many conventional insecticides (Whalon et al., 2011). Integrated pest management program (IPM) is a classical approach to overcome and manage the resistance problem. However, the limited availability of natural enemies is one of the major constraints in effective biological control program against the CPB. Therefore, the contact, antifeedant and residual toxicity properties of plant extracts can be helpful as additional tool for effective control of this destructive pest (Gonzales-Coloma et al., 1998; Metsapul et al., 2001; Kutas \& Nadasy, 2005; Szczepanik et al., 2005; Gokce et al., 2005, 2006, 2012). The ancient Egyptians are considered pioneer in using Balanites plant (Zygophyllaceae) extracted oil against dipteran species (Thacker, 2002). Before the introduction of chlorinated hydrocarbon and organic phosphorus pesticides, the plant based insecticides had been commonly used for insect pest management (Isman, 1997). The negative impact of pesticides on environmental and human health encouraged the use of biopesticides for insect pest management. Biopesticides include both microorganisms and plant extracts. The plant-based compounds are mainly plant secondary metabolites, which are produced by plants under stress conditions especially during pest attack, drought and stress conditions (Bourgaud, 2001). Some of these secondary metabolites have insecticidal, anti-fungal and anti-bacterial properties and their use can be helpful if incorporated in agricultural pest management programs (Charlwood \& Rhodes, 1990). Neem oil provided successive and promising results against important agricultural pest species (Nitao, 1987; Pascual-Villalobos \& Robledoet, 1999; Chiasson et al., 2004; Rehman et al., 2015). More than 2000 plant extracts have been reported to have insecticidal properties against various insect species (Dev \& Koul, 1997; Koul, 2005). Beside this, the applicability of plant based pesticides is still very limited (Ahmed \& Grainger, 1988; Parakash \& Rao, 1996; Hassan \& Gokce, 2014).

The objectives of the current study are to evaluate antifeedant activity of three different plant extracts on $L$. decemlineata larvae, and to examine growth inhibition effects of plant extracts on the larvae using different concentrations.

\section{Materials and Methods}

\section{Collection of plant materials}

The plants samples were collected as described by Çam et al. (2012). Achillea millefolium and Humulus lupulus were collected during the spring and summer seasons of 2010 in Tokat, Turkey and Heracleum platytaenium was collected during the summer season of 2009 in Trabzon, Turkey. The plant parts, used in the study, were separated from other parts of the plant, spread on blotting papers in a dark room and left to dry at $24 \pm 2{ }^{\circ} \mathrm{C}$ for two weeks. After this process, the plant materials were well ground by using a mill (M 20 IKA Universal Mill, IKA Group, Wilmington, NC, USA). The samples were transferred into glass jars of $5 \mathrm{~L}$ and stored at $15 \pm 5{ }^{\circ} \mathrm{C}$. The information about the plants, analyzed parts and location of collection is presented in Table 1. 
Table1. Name of the plants species used in the study with analyzed parts and place of collection

\begin{tabular}{lllll}
\hline Botanical Name & Family & Analyzed part & $\begin{array}{l}\text { Location of the } \\
\text { Collection }\end{array}$ & GPS location \\
\hline Achillea millefolium L. & Asteraceae & Leaf, Stem, Flower & Tokat, Turkey. & $40^{\circ} 18^{\prime} 55^{\prime} \mathrm{N} 36^{\circ} 32^{\prime} 11^{\prime \prime} \mathrm{E}$ \\
Heracleum platytaenium Boiss. & Apiaceae & Leaf, Stem & Trabzon, & $40^{\circ} 38^{\prime} 44^{\prime \prime} \mathrm{N} 39^{\circ} 20^{\prime} 22^{\prime} \mathrm{E}$ \\
Humulus lupulus L. & Cannabaceae & "Cone" & Tokat, Turkey. & $40^{\circ} 21^{\prime \prime} 4^{\prime \prime} \mathrm{N} 36^{\circ} 30^{\prime} 41^{\prime \prime} \mathrm{E}$ \\
\hline
\end{tabular}

\section{Preparation of plant extracts}

Plant extracts were obtained through maceration method as reported by Alkan \& Gökçe (2012). About $200 \mathrm{~g}$ of each plant powders was put into a glass jar. For obtaining $H$. platytaenium extracts, hexane, ethyl acetate, and methanol were added into jars respectively according to their polarity range. The plant powder in the glass jar was firstly treated with hexane for 48 hours; afterward the solvent plant suspension was filtered through filter paper and separated from plant materials. Thereafter, ethyl acetate was added to the remaining plant material, and again materials were left in the jars with this solvent for 48 hours. After this operation, ethyl acetate extract parts were filtered through filter paper. Lastly, methanol was added to the plant materials, and same procedure was repeated. $H$. lupulus and $A$. millefolium extracts were prepared with the maceration method but only methanol was used as solvent. The solvents in the existing suspension were evaporated by using the evaporator, and plant residues were obtained. Methanol extracts of plants were transferred into glass tubes, and were kept in $4 \pm 1{ }^{\circ} \mathrm{C}$ in the refrigerator. The extracts were diluted with $70 \%$ acetone, and the concentrations used in single concentration tests and all other bioassays were prepared from these stock solutions.

\section{Rearing of potato beetles}

Colorado potato beetle larvae were continuously reared on potato plants (Solanum tuberosum, cultivar Granola) at Gaziosmanpaşa University Research Station in Tokat, Turkey during the study as described in Gökçe et al., 2006. The potato tubers were planted in a 0.2 ha potato field in the early spring of each year. CPB adults were released into the field when the potato plants were 3 to 5 leaves stage. The insects used in the studies were collected from the field colony. There was no pesticide application during the study.

\section{Antifeedant activity of plant extracts against CPB larvae}

Firstly, the single concentration experiments were conducted to evaluate the antifeedant activity of plants extracts $\left(A\right.$. millefolium, $H$. platytaenium, $H$. lupulus) against the $3^{\text {rd }}$ instar larvae of CPB. Before spraying with plant extracts, each leaflet area was measured using a digital planimeter (Placom KP-90N Digital Planimeter, Koizumi, Japan). The potato leaves were treated with the plant extracts at $5 \%$ concentration (w/v) or $70 \%$ acetone as control. The plant extracts were applied with a hand sprayer to develop a plant extract film layer on the treated leaf surface. Before releasing the larvae on leaves, the treated potato leaflets were left to dry at room temperature under a fume hood for 30 minutes. Then larvae were transferred individually onto treated leaflets and incubated at $26 \pm 1^{\circ} \mathrm{C}, 60 \% \mathrm{RH}$ (Relative Humidity) and a 16 light: 8 dark photo regimes. The leaflets that were treated as above were replaced every 24 hour for 7 days. The consumption area of each leaflet was measured after $24 \mathrm{~h}$ using the digital planimeter and the results were recorded. Total 10 replications were done in a randomized complete block experimental design (RCBD).

Further studies of antifeedant activities of plant extracts were carried out at three different concentrations i.e. $0.1 \%, 0.5 \%$ and $1 \%(\mathrm{w} / \mathrm{v})$ to evaluate interaction between concentration of plant extracts and leaflet consumption area. The treatment of leaflets and incubation of larvae were performed as described above. Total four treatments including the control were carried out with ten replication for each treatment. The randomized complete block experimental design was used for testing activities. 


\section{Growth inhibition effects of plant extracts on 3rd instar CPB larvae}

Totally three different concentrations i.e. $0.5 \%, 1 \%$ and $3 \%$ of $H$. platytaenium and $H$. lupulus plant extract were used to test the impact of plant extracts on larval growth. The potato leaflets were treated with plant extracts or $70 \%$ acetone as described above. The $3^{\text {rd }}$ instar larvae were initially weighed using a digital balance (Kern \& Sohn EG 2200-2NM, KERN \& SOHN GmbH, Balingen, Germany) and the result were recorded. The larvae were individually transferred onto the treated leaflets and incubated at above conditions for 3 days. The larvae were shifted on fresh treated leaves after every 24 hours. The final weights of each larva were recorded at the end of three days. Ten larvae were used in per concentration of each plant extract and the control. The experiment was performed using the randomized complete block experimental design.

\section{Statistical analysis}

Antifeedant activity results were analyzed with paired t-test using Minitab® software (McKenzei \& Goldman, 2005). Growth inhibition rate of CPB larvae was calculated using the below formula (Gökçe et al., 2012) that was modified from Abdelgaleil \& Al-Aswad (2005). The calculated growth rates were subjected Kruskal- Wallis test.

\section{$\mathrm{Gl}=(\mathrm{CWC}-\mathrm{TWC}) / \mathrm{CWC}$}

GI: Growth Index

CWC: Weight change in the control

TWC: Weight change in the treatment

\section{Results and Discussion}

\section{Antifeedant activity of plant extracts against CPB larvae}

The mean consumption areas of individual larvae in the single concentration test are presented in Table 2. The data showed that all treatments cause a reduction in mean consumed leaf area, except $H$. platytaenium after 24 hours. $H$. lupulus extract appear to be the most active extract with producing the minimum mean consumed leaflets area. The larvae showed avoiding feeding behavior on leaves treated with $H$. lupulus extract up to 48 hours but this behavior changed after 72 hours and average $0.04 \pm 0.01$ $\mathrm{cm}^{2}$ leaf area was consumed by each larva at that time interval (Table 2). The maximum leaf area among the treatments at all time interval was seen in $H$. platytaenium treated leaves $\left(1.49 \mathrm{~cm}^{2}\right)$ after 24 hours. However, there was a reduction in this treatment after that time period and average $0.04 \mathrm{~cm}^{2}$ and 0.05 $\mathrm{cm}^{2}$ leaf areas were consumed after 48 hours and 72 hours respectively. Also the $A$. millefolium treatment significantly reduced the consumed leaf area over the tested time period $(t=3.47 ; P<0.05)$.

Table 2. Antifeedant activity of a single concentration (5\%) of plant extracts on Leptinotarsa decemlineata larvae. Average consumed leaflets area $\left(\mathrm{cm}^{2}\right)$ per Colorado potato beetle larva

\begin{tabular}{ccccccc}
\hline \multirow{2}{*}{$\begin{array}{c}\text { Post } \\
\text { Treatment } \\
\text { hours }\end{array}$} & \multicolumn{5}{c}{ Mean consumed leaf area $\left(\mathrm{cm}^{2}\right) \pm$ Mean Standard Error } \\
\cline { 2 - 7 } & Treatment & Control & Treatment & Control & Treatment & Achillea millefolium \\
& $1.49 \pm 0.39$ & $1.49 \pm 0.29$ & $0.00 \pm 0.0^{*}$ & $2.79 \pm 0,63$ & $0.37 \pm 0.37^{*}$ & $2.17 \pm 060$ \\
\hline 24. hours & $0.04 \pm 0.29$ & $2.30 \pm 0.40$ & $0.00 \pm 0.0^{*}$ & $1.86 \pm 1,14$ & $0.27 \pm 0.17^{*}$ & $2.07 \pm 046$ \\
48. hours & $0.05 \pm 0.03^{*}$ & $3.29 \pm 0.81$ & $0.04 \pm 0.1^{*}$ & $5.84 \pm 0,86$ & $0.30 \pm 015^{*}$ & $2.95 \pm 055$ \\
72. hours & 0 &
\end{tabular}

* Indicates that the treatment is statistically different than control (paired test $-t)(P<0.05)$. 
The antifeedant activities of different concentrations of $H$. platytaenium, $H$. lupulus and $A$. millefolium plant extract are presented in Tables 3,4 and 5 respectively. In all treatments, there was no significant difference between the treatment and the control group at $0.1 \%$ concentration at all time intervals. The larvae consumed larger areas at $72 \mathrm{~h}$ in all treatments groups comparing with previous two time intervals.

In $H$. platytaenium extract treatments, the minimum leaf area $\left(1.18 \mathrm{~cm}^{2}\right)$ was consumed at $1 \%$ concentration treated leaflets after 24 hours as the maximum leaf area $\left(2.07 \mathrm{~cm}^{2}\right)$ was consumed in the $0.5 \%$ concentration treatment. As the incubation period was extended, the larvae consumed more leaflets area at 0.1 and $0.5 \%$ concentrations. The maximum leaf area $\left(4.79 \mathrm{~cm}^{2}\right)$ was consumed at $0.1 \%$ concentration after 72 hours as the minimum was seen at $1 \%$ concentration after $48 \mathrm{~h}$. Overall, the leaflets treated with $1 \% \mathrm{H}$. platytaenium extract showed the greatest antifeedant activity against the $3^{\text {rd }}$ instar larvae (Table 3) $(\mathrm{t}=5.86 ; \mathrm{P}<0.05)$.

Table 3. Antifeedant activity of different concentrations of $H$. platytaenium methanol extract on Colorado potato beetle larvae over time period

\begin{tabular}{lcccccc}
\hline \multirow{2}{*}{$\begin{array}{c}\text { Post } \\
\text { Treatment } \\
\text { hours }\end{array}$} & \multicolumn{7}{c}{ Leaf Feeding Area $\left(\mathrm{cm}^{2}\right) \pm$ Mean Standard Error } \\
\cline { 2 - 7 } & Treatment & Control & Treatment & Control & Treatment & Control \\
\hline 24. hours & $1.83 \pm 0.22$ & $1.62 \pm 0.27$ & $2.07 \pm 0.41$ & $1.56 \pm 0.20$ & $1.18 \pm 0.18$ & $1.79 \pm 0.28$ \\
48. hours & $1.37 \pm 0.22$ & $2.02 \pm 0.34$ & $1.30 \pm 0.20$ & $1.03 \pm 0.44$ & $0.65 \pm 0.28$ & $1.90 \pm 0.58$ \\
72. hours & $4.79 \pm 1.00$ & $4.61 \pm 0.89$ & $3.66 \pm 0.78$ & $4.99 \pm 0.90$ & $1.18 \pm 0.35^{*}$ & $5.18 \pm 0.58$ \\
\hline
\end{tabular}

* Indicates that the treatment is statistically different than control (paired test $-t)(P<0.05)$.

Antifeedant activity of $A$. millefolium extract at different concentrations experiment revealed that this plant extract had a significant antifeedant activity when it was applied $1 \%(\mathrm{w} / \mathrm{v})$ concentration. At lower concentrations of this extract, the larvae consumed similar leaflets area. At $0.5 \%(\mathrm{w} / \mathrm{v})$ concentration, the leaflet areas consumed after 48 hours and 72 hours were $1.82 \mathrm{~cm}^{2}$ and $1.58 \mathrm{~cm}^{2}$ respectively (Table 4 ). While after 72 hours the maximum leaf area $\left(3.57 \mathrm{~cm}^{2}\right)$ was consumed in the $0.1 \%$ concentration treatment, the minimum consumption leaf area $\left(0.81 \mathrm{~cm}^{2}\right)$ was recorded on the leaflets treated with $1 \%$ A. millefolium extract after 72 hours $(\mathrm{t}=3.46 ; \mathrm{P}>0.05)$.

Table 4. Antifeedant activity of different concentrations of $A$. millefolium methanol extract on Colorado potato beetle larvae at different time intervals

\begin{tabular}{ccccccc}
\hline \multirow{2}{*}{$\begin{array}{c}\text { Post } \\
\text { Treatment } \\
\text { hours }\end{array}$} & \multicolumn{5}{c}{ Leaf Feeding Area $\left(\mathrm{cm}^{2}\right) \pm$ Mean Standard Error } \\
\cline { 2 - 7 } & Treatment & Control & Treatment & Control & Treatment & Control \\
\hline 24. hours & $0.82 \pm 0.11$ & $1.13 \pm 0.22$ & $0.87 \pm 0.20$ & $1.75 \pm 0.23$ & $0.50 \pm 0.08^{*}$ & $1.68 \pm 0.29$ \\
48. hours & $1.50 \pm 0.37$ & $1.54 \pm 0.22$ & $1.82 \pm 0.50$ & $1.51 \pm 0.49$ & $0.22 \pm 0.76^{*}$ & $1.68 \pm 0.29$ \\
72. hours & $3.57 \pm 0.98$ & $3.26 \pm 0.41$ & $1.58 \pm 0.47^{*}$ & $4.50 \pm 1.03$ & $0.81 \pm 0.21^{*}$ & $2.59 \pm 0.51$ \\
\hline
\end{tabular}

* Indicates that the treatment is statistically different than control (paired test $-t)(P<0.05)$.

Testing of different $H$. lupulus extract concentrations for antifeedant activity showed that this plant extract significant reduced the feeding of CPB larvae when it was tested at $1 \%(\mathrm{w} / \mathrm{v})$ concentration. The maximum leaf area was consumed at $0.1 \%$ concentration with $1.07 \mathrm{~cm}^{2}$ area after 24 hours, while it increased to $1.64 \mathrm{~cm}^{2}$ and $7.32 \mathrm{~cm}^{2}$ leaf areas after 48 and 72 hours (Table 5). This could be related with increasing size of larvae before molting to the next stage. The minimum consumption of leaflet area was observed at $1 \% \mathrm{H}$. lupulus concentration i.e. $0.24,0.48$ and $0.68 \mathrm{~cm}^{2}$ leaf area after 24,48 and 72 hours respectively ( $\mathrm{t}=6.56 ; \mathrm{P}<0.05)$ (Table 5$)$. 
Antifeedant activity and growth inhibition effects of some plant extracts against larvae of Colorado potato beetle [Leptinotarsa decemlineata Say (Col: Chyrsomelidae)] under laboratory conditions

Table 5. Antifeedant effects of different concentrations of $H$. lupulus methanol extract on Colorado potato beetle larvae at different time intervals

\begin{tabular}{ccccccc}
\hline \multirow{2}{*}{$\begin{array}{c}\text { Post } \\
\text { Treatment } \\
\text { hours }\end{array}$} & \multicolumn{5}{c}{ Leaf Feeding Area $\left(\mathrm{cm}^{2}\right) \pm$ Mean Standard Error } \\
\cline { 2 - 7 } & Treatment & Control & Treatment & Control & Treatment & Control \\
\hline 24. hours & $1.07 \pm 0.20$ & $1.35 \pm 0.27$ & $0.91 \pm 0.14$ & $1.10 \pm 0.18$ & $0.24 \pm 0.06^{*}$ & $1.87 \pm 0.22$ \\
48. hours & $1.64 \pm 0.40$ & $1.34 \pm 0.35$ & $0.67 \pm 0.13$ & $2.29 \pm 0.86$ & $0.48 \pm 0.16^{*}$ & $1.84 \pm 0.34$ \\
72. hours & $7.32 \pm 1.27$ & $4.64 \pm 0.92$ & $1.13 \pm 0.37^{*}$ & $4.37 \pm 1.07$ & $0.68 \pm 0.19^{*}$ & $6.24 \pm 1.08$ \\
\hline
\end{tabular}

* Indicates that the treatment is statistically different than control (paired test-t) $(P<0.05)$.

Natural products or botanical pesticides are an excellent alternative to synthetic pesticides as a means to reduce negative impacts on the human health and the environment (Mohan et al., 2011). The antifeedant studies of various plants extracts with promising results against CPB were also reported in previous studies (Gonzales-Coloma et al., 1998; Kutas \& Nadasy, 2005; Szczepanik et al., 2005). Antifeedant activities of diterpenoid alkaloids isolated from Delphinium cardiopetalums DC. (Ranunculaceae) were tested against both Spodoptera littoralis Boisduval. (Noctuidae) and Leptinotarsa decemlineata and 15-acetylcardiopetamine was reported to be the most active alkaloids against CPB. Gokce et al. (2006) reported that $H$. lupulus extract showed promising results against $3^{\text {rd }}$ instar $L$. decemlineata larvae as reducing consumed leaflet areas. In their study, they measured the dry weight of leaflets rather than measuring the leaflet areas so that their findings are not comparable with ours.

\section{Growth inhibition effects of plant extracts on the $3^{\text {rd }}$ instar CPB larvae}

Growth inhibition effects of $H$. platytaenium and $H$. lupulus extracts against CPB larvae were examined on the $3^{\text {rd }}$ instars by testing different concentrations. The results indicate that both plant extracts had a similar growth inhibition effect of at tested concentrations. The maximum effect was observed at $3 \%$ concentration as the recorded indexes were 1.2 for the both plant extracts. There was a significant difference between the larval growth indexes that were recorded at different concentrations of $H$. platytaenium $(\mathrm{H}: 6.28 ; \mathrm{p}<0.05)$. As pointed out above, the maximum growth inhibition index was recorded at $3 \%$ concentration while it was 0.9 and 1.1 at $0.5 \%$ and at $1 \%$ concentrations respectively (Figure 1). These results showed that the larvae that were forced to feed on the plant extract treated leaflets lost weight during the experiment and showed no growth at all. Similar larval growth reduction of CPB was also reported by Gökçe et al., (2012) who tested different concentration of hops extract on CPB larvae and found that the growth rate was significantly affected at $40 \mathrm{mg} / \mathrm{ml}$ concentration.

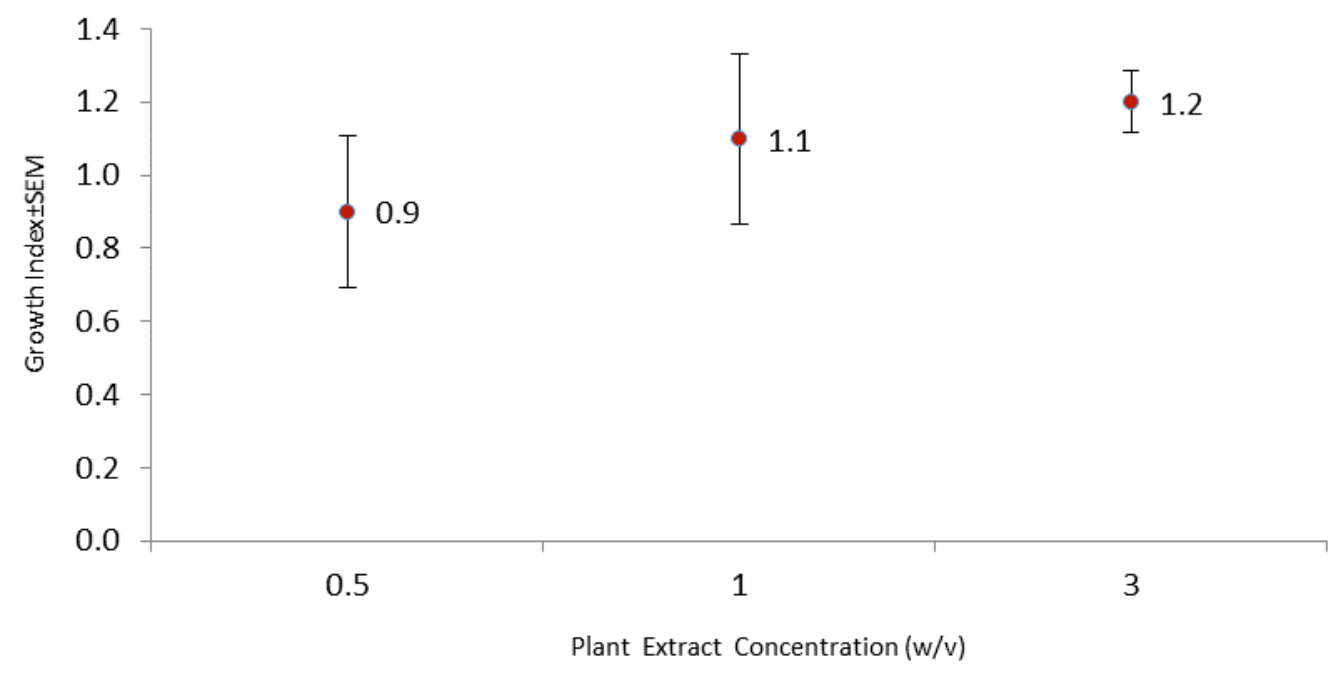

Figure 1. Effects of Heracleum platytaenium extracts on Colorado potato beetle larval growth. 
Testing of different concentrations of $H$. lupulus plant extracts revealed that this plant extract significantly reduced the larval growth of potato beetle, except at $0.5 \%$ concentration $(H=8.01 ; P<0.05)$ (Figure 2). The larvae that were fed with $0.5 \%$ of $\mathrm{H}$. lupulus extract treated leaflet gained some weight and their body weights similar to the control group larvae. However, there was a weight loss in the larvae when they were forced to feed on the leaflets that were treated with $1 \%$ and $3 \%$ of $H$. lupulus extract concentration. Our results are in accordance with Gokce et al. (2012) who examined the effects of different doses of $H$. lupulus extract on CPB adults and larvae and they reported that the growth inhibition index was around 1 at the highest concentration of the plant extract.

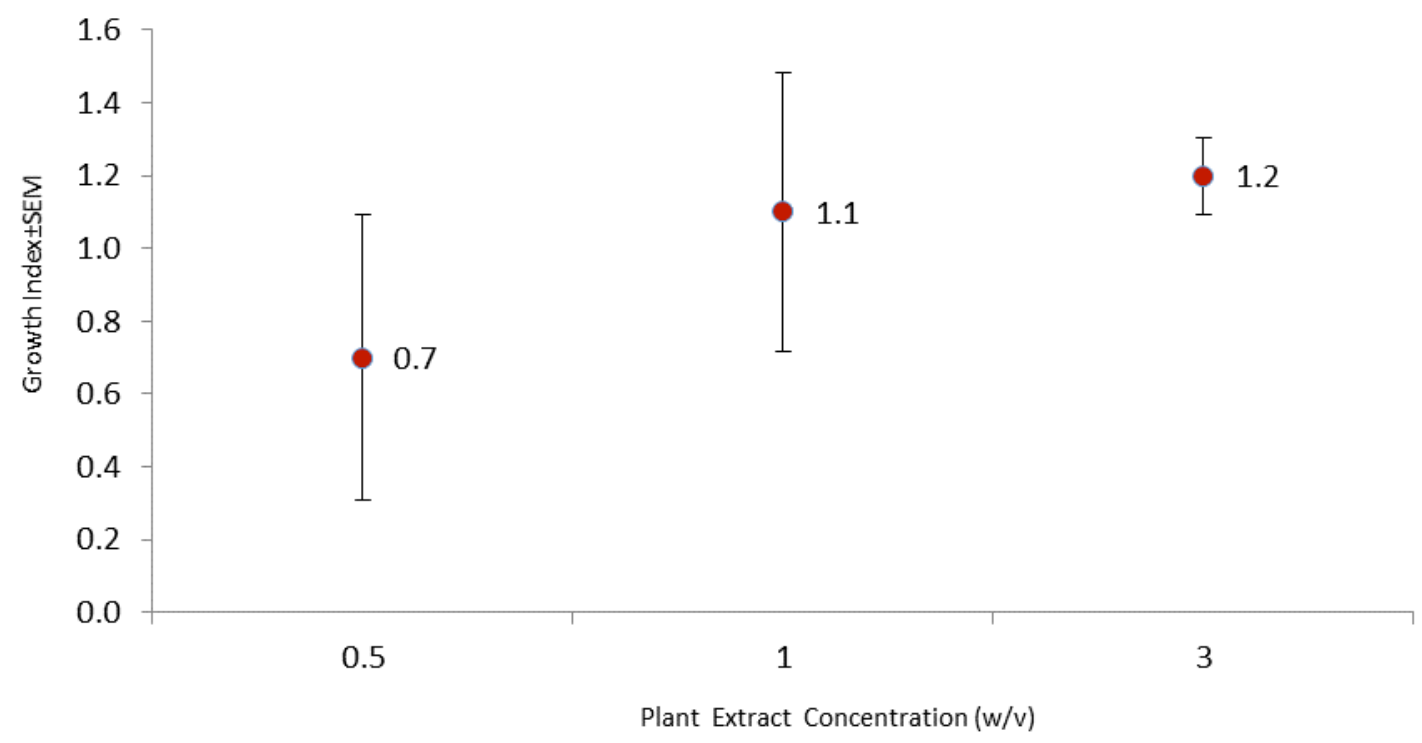

Figure 2. Effects of Humulus lupulus extract on Colorado potato beetle larval growth.

The results of the growth inhibition test showed that $H$. lupulus and $H$. platytaenium have strong activity against the $3^{\text {rd }}$ instar larvae. Application of these plant extracts may lead to larval growth retardation and even death of larvae due to starvation. Inhibition of CPB larval growth seems to be related with antifeedant activity of the extracts as shown in this study. However, the plant extracts may cause some physiological activity in the larvae that lead to inhibition of growth. Therefore, further studies are needed to test whether the growth inhibition of larvae observed in this study is related with any physiological effect of plant extracts on the larvae. Additional studies should be carried out to explore full potential of these extracts. Especially extraction, purification and characterization of the active compound(s) may lead to development of new tools in the controlling of this destructive pest.

\section{Acknowledgement}

This study was supported by Turkish Republic Prime Minister State Planning Organization (27DPT-01-07-01) and by the Ministry of Food, Agriculture and Livestock, General Directorate of Agricultural Research and Policy (TAGEM-BS-12 / 04-04 / 01- 04).

\section{References}

Abdelgaleil, S.A.M. \& A.F. El-Aswad, 2005. Antifeedant and growth inhibitory effects of tetranortriterpenoids isolated from three meliaceous species on the Cotton Leafworm, Spodoptera littoralis (Boisd.). Journal of Applied Sciences Research, 1(2): 234-241.

Afzal, M.B.S, S.A. Shad, N. Abbas, M. Ayyaz \& W.B Walker, 2014. Cross-resistance, the stability of acetamipridresistance and its effect on the biological parameters of cotton mealybug, Phenacoccus solenopsis (Homoptera: Pseudococcidae), in Pakistan. Pest Management Science, 71(1):151-58. 
Antifeedant activity and growth inhibition effects of some plant extracts against larvae of Colorado potato beetle [Leptinotarsa decemlineata Say (Col: Chyrsomelidae)] under laboratory conditions

Ahmed, S. \& M. Grainge, 1988. Handbook of Plants with Pest Control Properties. John Wiley\&Sons Limited, 470pp.

Alkan, M. \& A. Gökçe, 2012. Toxic and behavioural effects of Tanacetum abrotanifolium L. DRUCE (Asteraceae) stem and flower extracts on Sitophilus granarius and Sitophilus oryzae (Col., Curculionidae). Turkish Journal of Entomology, 36 (3): 377-389.

Bourgaud, F., A. Gravot, S. Milesi \& E. Gontier, 2001. Production of plant secondary metabolites; a historical perspective. Plant Science, 161: 839-851.

Charlwood, B. V. \& M. J. C. Rhodes, 1990. Secondary Products From Plant Tissue Culture, Oxford University Press, USA, 307pp.

Chiasson, H., C. Vincent \& B. Bostanian, 2004. Insecticidal properties of a Chenopodium based botanical, Journal of Economic Entomology, 97:1378-1383.

Christie, R. D., A. C. Sumalde, J. T. Schutz \& N. C. Gudmestad, 1991. Insect transmission of the bacterial ring rot pathogen. American Potato Journal, 68: 363-372.

Çam, H., A. Gökçe, İ. Kadıoğlu, Y. Yanar, N. Gören \& M. E. Whalon, 2012. Bitki ekstraktlarının Patates böceği [Leptinotarsa decemlineata Say (Coleoptera: Chrysomelidae)]'nin farklı dönemleri üzerine mide zehiri ve rezidüyel toksisite etkileri. Türkiye Entomoloji Dergisi, 36 (2): 249-254.

Dev, S. \& O. Koul, 1997. Insecticides of Natural Origin. Harwood Academic Publishers, The Netherlands, 222 pp.

Gonzalez-Coloma, A., A. Guadano, C. Gutierrez, R. Cabrera, E. Pena, G. Fuente \& M. Reina, 1998. Antifeedant Delphinium diterpenoid alkaloids. structure- activity relationships. Journal of Agricultural and Food Chemistry, 46: $286-290$.

Gökçe, A., L. L. Stelenski \& M. E. Whalon, 2005. Behavioral and electrophysiological responses of leafroller moths to selected plant extracts. Environmental Entomology, 34: 1426-1432.

Gökçe, A., M. E. Whalon, H. Çam, Y. Yanar, İ. Demirtaş \& N. Gören, 2006. Plant extract contact toxicities to various developmental stages of Colorado potato beetles (Coleoptera: Chrysomelidae). Annals of Applied Biology, 149:197-202.

Gökçe, A., R. Isaacs \& M. E. Whalon, 2012. Dose-response relationships for the antifeedant effects of Humulus lupulus extracts against larvae and adults of the Colorado potato beetle. Pest Management Science, 68: 476-481.

Hassan E. \& A. Gökçe, 2014. "Production and Consumption of Biopesticides, 361-379pp." In: Advances in Plant Biopesticides (Ed: Singh Dwijendra) Springer, $401 \mathrm{p}$.

Isman, M. B., 1997. Neem and other biological insecticides: Barriers to commercialization. Phytoparasitica, 25(4): $239-249$.

Koul, O., 2005. Insect Antifeedants. CRC Press, Florida, 1005pp

Kutas, J. \& M. Nádasy, 2005. Antifeedant effects of several plant extracts on Colorado potato beetle larvae. Acta Phytopathologica et Entomologica Hungarica, 40: 355-365.

McKenzie, J.D. \& R. Goldman, 2005. The student guide to MINITAB release 14. Pearson Education.

Metspalu, L., K. Hiiesaar, J. Jõudu \& A. Kuusik, 2001. The effects of certain toxic plant extracts on the larvae of Colorado potato beetle, Leptinotarsa decemlineata (Say). Practice oriented results on the use of plant extracts and pheromones in pest control: Proceedings of the International Workshop, Tartu, Estonia, 24-25 January.

Mohan, M., Z. Haider, H. Andola \& V.K. Purohit, 2011. Essential oils as green pesticides: for sustainable agriculture. Research Journal of Pharmaceutical, Biology and Chemical Sciences, 2: 100-106.

Mota-Sanchez, D., M. E. Whalon, E. Grafius \& R. Hollingworth, 2000. Resistance of Colorado potato beetle to Imidacloprid. Resisitance Pest Management Newsletter, 11:31-34.

Nitao, J. K., 1987. Test for toxicity of Coniine to a polyphagous herbivore, Heliothis zea (Lepidoptera:Noctuidae), Environmantal Entomology, 16, 656-659.

Parakash, A. \& J. Rao, 1996. Botanical Pesticides in Agriculture. CRC pres. LewisPublishers, pp 443.

Pascual-Villalobos, M. J. \& A. Robledoet, 1999. Anti-insect activity of plant extracts from the wild flora in southeastern Spain. Biochemical Systematics and Ecology, 27: 1-10. 
Rehman, H., M. Nadeem, M. Ayyaz \& H.A. Begum, 2015. Comparative Efficacy of Neem Oil and Lambdacyhalothrin against Whitefly (Bemisia tabaci) and Jassid, (Amrasca devastans Dist.) in okra field. Russian Journal of Agircultural Sciences. 41: 138-145.

Stewart, J. G., G. G. Kennedy \& A. V. Sturz, 1997. Incidence of insecticides resistance in population of Colorado potato beetle, Leptinotarsa decemlineata (Say) (Coleoptera: Chrysomelidae) on Prince Edward Island. Canadian Entomologist, 129: 21-26.

Szczepanik, M., I. Dams \& C. Wawrzenczyk, 2005. Feding deterrent activity of terpenoid lactones with the pmenthane system against the Colorado potato beetle (Coleoptera: Chrysomelidae). Environmental Entomology, 34:1433-1440.

Thacker, J. M. R., 2002. An introduction to Arthropod Pest Control. Cambridge University Press, Cambridge, 343 pp.

Whalon, M. E., D. Mota-Sanchez, R. Hollingworth \& L. Duynslager, 2011. Arthropod Pesticide Resisitance Database. ( Web page: http://www. Pesticideresistance.com) (Accessed date: May 2014). 